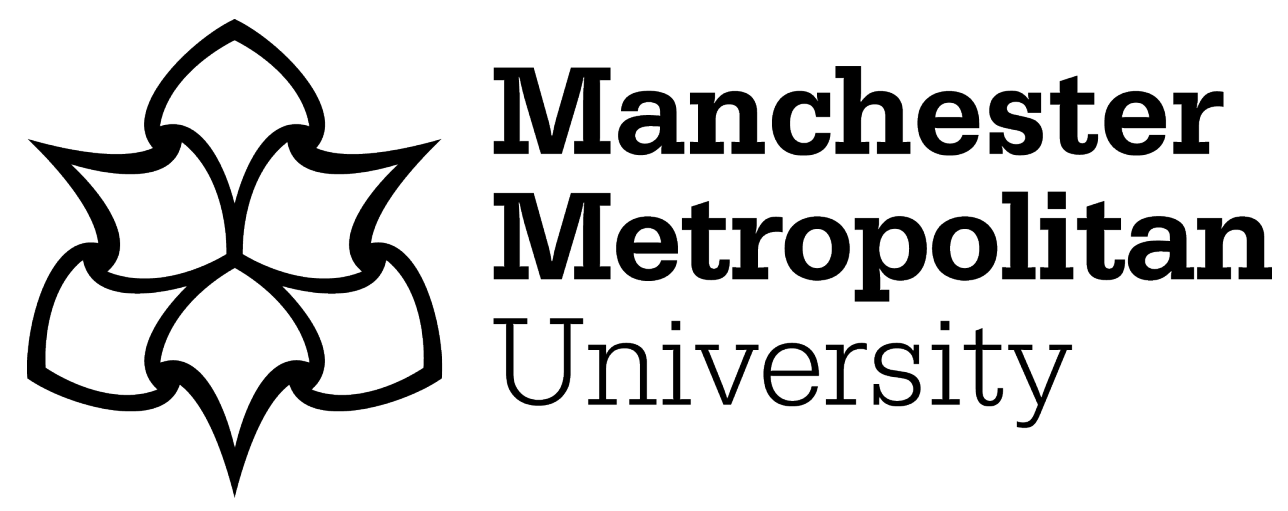

Badwan, Khawla ORCID logoORCID: https://orcid.org/0000-0003-1808724X (2021) Agency in educational language planning: perspectives from Higher Education in Tunisia. Current Issues in Language Planning, 22 (1-2). pp. 99-116. ISSN 1747-7506

Downloaded from: https://e-space.mmu.ac.uk/624460/

Version: Accepted Version

Publisher: Taylor \& Francis Group

DOI: https://doi.org/10.1080/14664208.2019.1700056

Please cite the published version 


\title{
Agency in educational language planning: perspectives from Higher
}

\section{Education in Tunisia}

\author{
Khawla Badwan \\ Department of Languages, Information and Communications, Manchester Metropolitan \\ University, $\mathrm{M} 156 \mathrm{BH}$.
}

Email: K.Badwan@mmu.ac.uk

\begin{abstract}
Post-modern approaches to language policy have emphasised the role of agency in implementing and appropriating language policies (Ricento, 2000; Johnson and Johnson, 2015). While agency is often perceived in positive terms, Liddicoat (2019) calls on language policy researchers to investigate its problems and constraints. This article discusses the interplay of structure and agency in educational language policies in Tunisian higher education, a sector characterised by a 'benign neglect' (Piller, 2016) approach to language policy. While doing so, it responds to Fenton-Smith and Gurney's (2016) observation that higher education contexts remain largely underexplored in the language policy scholarship. The article uses data from 12 semistructured interviews from local higher education stakeholders in order to explore how their agency is exercised, rejected and contested. The study demonstrates that while agency creates room for flexibility and the ability to respond to changing local demands and aspirations, it can also cause problems such as inconsistency, uncertainty, and the reproduction of social inequalities.
\end{abstract}

Keywords: language policy, agency, higher education, power, Tunisia

\section{Introduction}

Language planning research has emphasised notions of power, governmentality, authority, and official policies as the providers of top-down rules about the promotion, maintenance or suppression of certain languages in public domains. Educational policies remain one of the most powerful mechanisms for implementing, protecting and maintaining official language 
policy rules, leading to the reproduction and perpetuation of the sociolinguistic statuses of certain language(s) in the nation-state (Davis, 1994; Spolsky, 2012; Walter and Benson, 2012). However, the relationship between official policies and local implementations via and within educational institutions is not always straightforward. To this end, language policy research has offered different approaches to theorise the relationship between policyproviders and policy implementers.

One way to describe this relationship is based on foregrounding the multi-layeredness of language policy processes. To this end, different layer metaphors have been developed in the literature. For instance, Ricento and Hornberger (1996) and Hornberger and Johnson (2007) propose a metaphorical language policy and planning onion to discuss the complex spaces where agentive local actors implement or resist policy initiatives. Other researchers talk about three strata or layers: macro, meso and micro levels of language planning (Zhao and Baldauf, 2012; Baldauf, 2006; Marriott, 2006). While the macro-level is associated with official government policies, the meso level is more nuanced as it involves multiple interpretation and implementation processes within educational institutions. The micro-level, on the other hand, is often used to refer to 'actions and decisions of lecturers operating alone or in small groups' (Fenton-Smith and Gurney, 2016, p.74). Similarly, Johnson (2013) uses a layer metaphor with three layers of language planning process: creation (at state-level), interpretation (by the creators and those meant to implement the policies), and appropriation (by those at the receiving end of the policies). While this layering offers valuable insights into the complexity of language planning processes, it indicates the difficulty of determining where the boundaries between these layers are. Commenting on this, Johnson and Johnson (2015, p. 223) maintain that 'in reality [these processes] can all occur at every level'. In line with the complexity of language planning process, there has been a focus on the different stakeholders or actors involved in such stages or processes. These roles are 
broadly aligned with the three macro, meso and micro layers. First, there are policy creators, providers, or legislators. Second, there are policy mediators, actors, arbiters, or implementers. Third, there are policy receivers or those affected by the implemented policies. Yet, there are more nuanced roles that float between macro and meso levels such as those played by consultants, strategic planners, and research academics. Other researchers use terms such as 'from the top', or 'from below', 'top-down', or 'bottom-up' to describe stakeholders' relation to power (Shohamy, 2009; Horner, 2009).

These approaches have provided valuable insights into the complexity surrounding language planning processes. However, they seem to focus on a rather limited group of stakeholders such as official legislators, senior management within educational institutions and teachers. These stakeholders are usually sufficient to describe language planning in some school contexts. However, language planning in university contexts can be affected by a larger pool of influencers. This encourages language policy researchers to think about additional stakeholders that affect the language planning processes in higher education contexts. Doing so creates an opportunity to understand language policy in more inclusive terms (Spolsky, 2009; Wee, 2016).

In this research, the experience of Tunisian higher education demonstrates that language-planning processes are significantly influenced by factors such as employers' linguistic expectations, global aspirations, national tensions, student mobility, access to academic references, and parental involvement. Such influencers direct the attention to English at a time when the current de facto educational language policies promote French. The absence of official educational language policies, or what Piller (2016) refers to as a 'benign neglect' approach to language planning, has created room for agency exercised by local educational stakeholders. This agency is supported by wider societal, neoliberal aspirations such as social mobility, economic development, and internationalising the 
educational sector. At the same time, this agency has created a sense of uncertainty around the employability of university graduates, and around the synergy between higher education objectives, workplace demands and expectations of university graduates.

This paper explores how agency is claimed, practiced and contested in the creation of local language policies in Tunisian higher education. The importance of this research stems from three main areas. First, it responds to Fenton-Smith and Gurney's (2016) call for more research on language policy and planning in higher education contexts; an area, they argue, that has remained under-researched. Second, it offers valuable contributions to existing understandings of agency in educational language planning, with a particular focus on how it is claimed and contested by social actors in local contexts. Finally, it presents a discussion about the negative side of agency while avoiding common celebratory discourses of agency in education.

Following this introduction, I provide an overview of the research context. After that, I discuss the interplay of structure and agency in educational language policy before I explain how I use the term 'language policy influencers', rather than 'arbiters', to widen the scope of influencers so as to include the role of domains such as the workplace, the family, and mobility aspirations. Subsequently, I address the methodological aspects of the study. The findings that follow are accompanied by a discussion of the significance of this work for understanding agency in educational language planning.

\section{Research Context: Languages in Tunisia}

Tunisia is a North African country with a population of $11,759,874$ people, according to the latest United Nations estimates (Worldometers, 2019). Tunisia gained its independence from France in 1956. Its income level is currently classified by the World Bank as lower middle income (World Bank, 2020). 
Sociolinguistically, Tunisia is a highly multilingual country. Walking in the streets of Tunisia, one can see street signs in different varieties of Arabic (Modern Standard Arabic, Tunisian Arabic or Darija), French and English. Other street signs write French or English words in Arabic script or vice versa. Individuals are highly multilingual, drawing fluidly and flexibly on their Arabic, Berber, English and French repertoires. 'Language' in Tunisian everyday communicative practices is creative, hybrid, and is indeed an act of 'languaging', defined as the ability to employ whatever linguistic features individuals have at their disposal with the intention of achieving their communicative aims (Jørgensen, 2008, p.169).

With reference to official language policies in Tunisia, the Tunisian constitution mentions Arabic as the official, national language of Tunisia, with no mention of the role and/or status of French and English. A common observation that was noticed during the process of reviewing official documents regarding languages in Tunisia is that the foreign languages in Tunisia are not explicitly specified. The assumption that French is the first foreign language and English is the second foreign language in Tunisia is not based on official documents that articulate or specify this ordering. Rather, it is perhaps a reflection of the order in which these languages are introduced in the public school educational system. French and English are taught as foreign languages: French is currently introduced as a foreign language subject at Grade 3 of primary school, whereas English is introduced at Grade 6.

With reference to higher education, and based on fieldwork observations and interview data, most university subjects are taught through the medium of French, with the exception of some disciplines such as history, philosophy, journalism, Islamic studies and Arabic literature which are taught in Standard Arabic. Some universities in the capital city of Tunis have started to gradually introduce some university courses in English. 2010 witnessed the opening of Tunis Business School, the first and only public institution in Tunisia that uses 
English as the main language of instruction. Commenting on this educational initiative, the School's website states that, 'the launch of this institution is in tune with government efforts to boost the Tunisian economy, improve competitive standards, and develop off-shore activities'.

The absence of an official language policy regarding the language(s) of instruction at tertiary level in Tunisia is an example of a 'benign neglect approach' (Piller, 2016, p.205), whereby the state does not interfere with the linguistic choices of educational institutions. This approach has serious limitations because 'state business, particularly education, always has to be conducted in a particular language and the language chosen for that task is favored eo ipso' (Piller, 2016, p. 205). While researching language policy in Tunisian higher education, I was reminded of Johnson's (2013, p.116) questions when he asks, 'who has the right, or is positioned as having the right, to control the creation, interpretation, and appropriation of language policy?'. Through semi-structured interviews with different educational stakeholders in Tunisian universities, this paper aims to explore the role of local actors in policy creation and implementation at university level.

\section{Structure and Agency in educational language policy}

The concepts 'structure' and 'agency' are often discussed in social science research as crucial factors for societal change (Chouinard, 1997). The importance of these concepts stem from their ability to explain the nature and use of power, and how different groups implement, negotiate or resist power structures. Language policy research continues to view language as a site of struggle under power influences (Desai, 1995; Phillipson, 2003; Canagarajah, 2005, Bilaniuk, 2005); hence, it is common for language policy researchers to engage with the structure-agency debate (Johnson and Johnson, 2015).

Language, as an everyday discursive practice, is not only a means of communication 
but a marker of belonging, a choice on affiliation, and a means of being in the world (Harvey, 2017). It is fluid, complex and translingual (Otheguy et al, 2015). Yet, in language policy contexts, language attracts different connotations because it is viewed as a marker of nationhood, loyalty, conformity and uniformity (Shohamy, 2006). Language, in such contexts, is regulated and assigned statuses and functions that reproduce language ideologies, which affect how individuals make decisions about what is 'right and wrong, beneficial and non-beneficial' (Block and Corona, 2019, p.3). Such language ideologies , or what Spolsky (2004) refers to as the ideological realm, are partly shaped by governmentality, defined as 'practices of government [which] are deliberate attempts to shape conduct in certain ways in relation to certain objectives' (Foucault,1980 cited in Rose, 1996). Language policies 'from the top' (re)produce ideologies in favour of certain languages and create a mechanism of linguistic stratification (Piller, 2016) that renders languages to be socially unequal. However, Pennycook $(2002,2006)$ calls on language policy researchers to redirect the focus from structure i.e. official policies and dominant ideologies to agency through researching local discourses and practices.

Agency in social sciences is used to explain individuals' social action (Hollis, 1994). Martin (2004, p.136) defines agency as 'the capability of persons to make choices and act on these choices'. He engages with a philosophical debate on the relationship between free will and determination when discussing agency. On the one hand, there is an argument that agency stems from free will and assumes that individuals determine their choices and actions. On the other, there is a view that free will does not exist and that self-determination, itself, is determined by sociocultural factors. In such circumstances, Martin (2004, p.137) explains, some philosophers argue that, 'persons cannot be said to be agents in the appropriate way'. Biesta and Teddar (2006) disagree with this view and present an ecological understanding of agency. They argue that agency does not reside in individuals. Rather, it is an emergent 
phenomenon that results from the interplay of individual efforts, resources and contextual and structural factors. This means that agency is not something that people inherently have, but is something that individuals do in response to a range of ecological factors (Biesta et al, 2015). In addition, Emirbayer \& Mische (1998) suggest that agency reflects the interplay of past influences (beliefs, experiences), engagement with the present (an evaluative dimension that engages with contexts of action) and orientations towards the future (imagined achievements). They see agency as a 'temporally constructed engagement with different structural environments' (1998, p. 970). This means that it is important to understand agency not only in terms of individuals' actions but also in light of the time and context of this action.

Language policy researchers use agency to refer to micro-level processes, operating at local levels to meet institutional demands or aspirations. Aligning with this understanding, Liddicoat and Taylor-Leech (2014) talk about how local actors assume agency to address local language needs bearing in mind available resources. Similarly, Baldauf (2006) and Fenton-Smith and Gurney (2016) note that micro-level agents demonstrate agency by creating a language policy or a plan that does not necessarily derive from larger macropolicy, but relies on their response to their own local needs. This suggests that language policy researchers embrace an 'ecological understanding of agency', aligned with the work of Biesta and Teddar (2006).

Moving to discuss the relationship between actions and ideologies, Rampton and Holmes (2019) assert that language ideologies are plural, personal and can be reshaped by practices. Here, they draw a distinction between 'dominant or residual ideologies' which tend to be shaped by formal structures and what Williams (1977) calls 'emergent ideologies'. Commenting on 'emergent ideologies', they explain that, 'ideologies emerge when people do things which don't fit the mould, when they recognise that they're doing something different, 
and start to build it up' $(2019$, p. 6). This suggests that agency, framed around action, can potentially reshape some language ideologies which could ultimately affect structures and policies at local levels.

However, it seems that there is a two-way relationship between action and ideology. There are actions that reshape (emergent) ideologies and there are actions that stem from (dominant) ideologies (Rampton and Holmes, 2019). Not only does this suggest that ideologies are dynamic and plurilithic (Pennycook, 2007), but it indicates that language policies are not static (Johnson, 2013, p.119), as well as nonlinear (Ricento, 2016, p. 279). Aligning with this view, Schiffman (2006, p.112) talks about the role of cultural notions about language when he says:

It is important to view language policy as not only the explicit, written, overt, de jure, official, and top-down decision making about language, but also the implicit, unwritten, covert, de facto, grass-roots and unofficial ideas and assumptions, which can influence the outcomes of policy-making just as emphatically and definitively as the more explicit decisions.

In the Tunisian context, the influence of de facto ideas about language is very prominent, as they affect local decisions about which language to use as the medium of instruction. At the absence of official educational language policies, local teachers and heads of departments can arguably been seen as the final providers and implementers of language policies. The question that begs to answer here is where these assumptions about language come from. On the one hand, Ball (2006) argues that social agents tend to align their actions with dominant discourses, which means that they try to gain power and legitimacy through normalising and embracing dominant ideologies and the structures that support them. French, in Tunisia, has a prestigious status. Daoud (2011, p.15) explains that one of the key factors for 
maintaining the current status of French in Tunisia is that most parents were educated in the French school system and they 'continue to perpetuate their language/cultural profile by sending their children to French-medium schools and French-medium universities abroad'. On the other hand, this study provides evidence that social agents do not always rely on dominant ideologies (which support the status of French in Tunisia). Instead, they try to be empowered by embracing global, neoliberal ideologies to reinforce the status of English in post-colonial Tunisia. This has created what Daoud (2011, pp.9-10) describes as:

an ongoing ideological, sociocultural rivalry between Arabic and French, an intensified pragmatic, functional competition between French and English, and an overall sense of deteriorating competence in all these languages among the younger generations, coupled with an unsettled cultural orientation.

As expected, this rivalry is further reflected in educational language policies at tertiary level as will be further explained in this paper.

\section{Language policy 'arbiters': a note on terminology}

Johnson and Johnson (2015) introduce the term 'language policy arbiters' in their research on language policy appropriation. They maintain that individuals in different levels (macro, meso and micro) do not possess the same amount of power and authority. As a result, they argue for the need to use the term 'language policy arbiters' which they define as 'individuals who have a disproportionate amount of impact on language policy and educational programs' (2015, p. 222). In their study on language policy appropriation in US schools that follow the same state-level programme but end up with different language policy practices, they highlight the role of arbiters such as educators, and administrators, and how they draw upon their language ideologies, utilising existing parental support, to reinforce their linguistic positions in relation to language planning. Furthermore, Johnson and Johnson 
(2015, p.225) contend that language policy power is divided between arbiters (those who get a policy created, interpreted or appropriated) and those positioned as mere implementers.

While I agree with the view that social agents in educational settings wield a disproportionate amount of power, I hesitate to use the term 'arbiters' in this study for three reasons. First, the Tunisian higher education context has no official language policy to appropriate or interpret; these are key roles played by the language policy arbiters in Johnson and Johnson's (2015) study. Second, the term 'arbiters' seem to be used to refer to individuals with real policy-making authority. This is evident in Johnson and Johnsons' (2015) comment on the role of parents when they say, 'while it could be argued that parents are arbiters because they exert so much influence, in the end they have no real policy-making authority' (p.238). This study explains that there is a large pool of influencers who (re)shape language ideologies and visions for educational policies. Still, they do not always possess policy-making authority. Third, the term 'language arbiters', as Johnson and Johnson (2015, p.238) explain, 'make[s] the process more hierarchical and structured'. While this might be appropriate when researching language policies in schools, educational language policies at universities are in flux because universities are affected by a wide array of local, national and global influences. This means that language policy powers at universities are not exclusively shared between arbiters and implementers, but there are other external influencers with a disproportionate amount of power. Based on the reasons outlined above, I will use the term language policy 'influencers' when discussing the findings of the study reported herein. As such, I will be able to refer to a wider group of influencers, responding to Spolsky (2009) and Wee's (2016) call for expanding the scope of language policy domains to include the family, the industry, the workplace and various institutions in order to understand language policy in more inclusive terms. 


\section{The study}

The data presented in this study are part of a larger British Council research project that investigates the role and status of English in Tunisian higher education. This paper, however, only focuses on exploring how decisions about the language of instruction are made at local levels and the considerations that feed into such decisions. The data featured in this paper comes from semi-structured interviews with 12 language policy influencers ( 2 heads of department, 6 university lecturers and 4 university students). Participants by gender are 7 male and 5 female. Average interview duration is 37 minutes.

With reference to the language(s) of the interview, the participants were asked to choose whether they preferred to be interviewed in Arabic or English, as I am is an expert user of both languages. Nine interviews were conducted in English whereas three interviews were mainly in Arabic, with some translanguaging practices (Creese and Blackledge, 2015) that included French and some English. While I was accompanied by an expert user of French to offer ad hoc oral and written translations, I was the only interviewer during the data collection process.

The following table (Table 1) shows some details about the participants such as: job title, gender, discipline, interview duration, and the language of interviews.

\section{-Insert table (1) here}

Research data was analysed following Johnson and Johnson's (2015, p.229) thematic approach of identifying 'who the arbiters are and why they make the decisions they make'. Replacing 'arbiters' with 'influencers', the analysis captures wider influencers that (re)shape beliefs about language in education. Therefore, this section is structured around the different influencers, while highlighting the role of other domains in educational language planning. 
After that, I move on to discuss the theme of 'contesting agency', in light of two interviews with university lecturers.

\section{Findings}

In this section, I outline key language policy influencers in Tunisian higher education, demonstrating their agentive role in making changes, or challenging existing practices associated with the language of instruction at tertiary level. As explained in Section 2, the absence of an official language policy regarding the language(s) of instruction at tertiary level can be regarded as an example of a 'benign neglect' (Piller, 2016) approach. In such contexts, agency plays the role of policy creation and implementation. It is important to reiterate that the influencers listed below do not have equal distribution of, or access to, institutional power. The order of presenting the influencers is framed around institutional hierarchy, without assuming that the influencers mentioned first are always the most influential.

\subsection{Language policy influencers in Tunisian higher education}

\subsubsection{Heads of departments}

During the study, I interviewed two heads of departments to discuss existing language practices associated with the language(s) of instruction in their departments. Both noted that the use of French as the medium of instruction is a conventional practice, rather than a mandated policy. The following quotation provides a historical perspective into this linguistic convention:

I: Why are many subjects taught through French at university level?

H1: Right after independence, France showed interest to help and established an educational system in Tunisia similar to what they have in France. They sent teachers who chose to teach as a substitute to doing military service so we received many French teachers. This is how we have the French system now. 
This head of department works at the first public institution to teach through the medium of English. During the interview, he explained how the school made an internal decision, underpinned by market dynamics and soft power, to teach in English. As such, they wanted to have a marker of distinction in the Tunisian educational sector:

I: How did you decide on the language of instruction in the school?

H1: From the start, we agreed that [this school] should not be one more extra school that teaches business. It should be a distinctive school so we designed it in the American way with lots of emphasis on soft skills, critical thinking in addition to knowledge. This combination was very attractive. We received some American grants and scholarships. People then developed the understanding that studying in English at this school offers an opportunity to go to the US for one summer as part of exchange programmes. So the quality of students was automatically upgraded.

(Head of Department 1: Business Studies)

This quotation highlights the power and influence of external domains such as the educational market, access to foreign aid, and graduates' employability. Together, these factors played a major role in the process of creating a language policy that dictates the need to teach in English, rather than French. Therefore, the agency of this school was supported by external neoliberal pressures and soft powers, which created positive language ideologies in favour of English. When the head of department says, 'the quality of students was automatically upgraded' he means that his institution selects high-achieving students based on English entry exams to ensure that their students can cope with English as a medium of instruction.

The second head of department explains the growing importance of English in Tunisia. He talks about the importance of English as the language of research and publications and how university lecturers are expected to access up-to-date research, which is usually published in English. Here, he explains how they, as a department, made collective decisions on who teaches what in what language: 
I: How do you make decisions on which languages to teach through?

H2: We try to teach some courses in English. We started by checking who is comfortable to teach his or her course in English. We also allow students to submit PhD dissertations in English. We don't have any problem with the language. Students can choose the language of submission. The majority of students submit in French. We cannot remove the French language. It is the history of the people, language of the people and their education... We cannot deliver the information in English. About 10\% of our teachers studied in Anglophone countries and these teachers only can teach in English.

(Head of Department 2: Agricultural Engineering)

This quotation explains how this department exercises agency by involving the lecturers in the decision-making process, which is mainly based on lecturers' abilities to teach advanced subject-knowledge in English. At the same time, this agency is constrained by the limited number of lecturers who can teach in English and by students' limited linguistic proficiency in English. Here, Head of Department (2) is aware of the status of French in the society and is worried that teaching through English can disadvantage some students. When he says French is 'the history of the people, language of the people and their education', he argues that decisions to change the medium of instruction can have acute consequences for his students. This is an example of an ecological understanding of agency (Biesta and Teddar, 2006), whereby decisions are made while considering wider sociocultural factors.

This section has highlighted the roles played by heads of departments in creating language policies that suit their local resources, demands and aspirations. It also demonstrates the influence of external pressures such as workplace, foreign aid, and access to publications. At the same time, local constraints associated with lecturers and students' limited linguistic proficiency in English do not make the implementation of these rules a straightforward process. The examples presented here explain the liquidity and nonlinearity of language policy processes which largely depend on who is able to teach in English and the extent to which students can cope with this linguistic change. 


\title{
6.1.2 University Lecturers
}

University lecturers are key influencers in this educational context. They exercise agency by choosing the language(s) of instruction for their classes, assigning reading recommendations, and choosing the language of assignments, oral presentations, reports, exams, etc. In this section, I present data from two university lecturers and two students talking about the role of their lecturers. Together, this section shows how lecturers exercise agency, highlights some of the constraints of such agency and discusses the impact of wider domains on lecturers' beliefs about language in education.

In the following quotation, a computer-engineering student talks about the role of lecturers in creating language policies:

\begin{abstract}
A lecturer tried to teach the first session in English and he asked us to present ourselves in English and to do presentations in English. First, it was weird but then we felt good for a change. Most of the students did not feel that they were able to do this task. He made us more attracted to the class. We expect that this will work.
\end{abstract}

(Student 1: Computer engineering)

In this example, the lecturer acts as a language policy maker who sets out rules about what language to be used in the classroom. Here, the lecturer does not consult the students to check if the new rule of using English would work for all students and whether some might be disadvantaged by it, given their limited linguistic proficiency in English.

Other lecturers exercise agency while negotiating with the students. In an interview with a university lecturer, he explains that:

I give two courses here. One in French and the other one I design the slides in English and I ask them whether they prefer to have the lecture delivered in English or French. Most students choose French... I advise our PhD students to write in English. It is easier for them to write in English because all their references are English. Now the trend is towards English. 
During the interview, the lecturer emphasised the importance of including students in decisions about how they are taught at university. This, in return, assigns some level of influence to university students.

Other university students and lecturers do not agree that students need to be consulted in decisions pertaining languages of instruction. Some lecturers expressed the view that university students need to adjust to lecturers' decisions because lecturers have the authority and knowledge. The following quotation from an architecture student shows how she refuses to claim agency by assigning full responsibility for language policy decisions to her lecturers:

We learn whatever we are given. If we are given a course in English, we will have to learn it. If they decide to teach in French, we adapt. It is not up to me to decide.

(Student 2: Architecture)

The second software engineering lecturer rejects claims of agency by referencing conventional, de facto rules about teaching in French. Here, she argues that she is not in a position to decide on the language of instruction for her classes:

I: can you make your own decision to teach in English instead of French?

L2: It is a question of meeting students' expectations. They sign up to universities and they know the language of instruction is French. There is a hidden contract or law that we need to respect. If we suddenly switch from French to English some students will complain.

(Lecturer 2: Software engineering)

During the interview, this teacher was supportive of introducing English as the language of instruction. She spoke about the importance of English for research, publication, jobs, scholarships and social mobility. However, she denies that she has the agency to change existing linguistic practices because she is aware that students come to study at her institution 
with the expectation that they will be taught in French. That said, she later expresses some uncertainty:

The boundaries are not clear anymore. Students today are different from when I was a student. I did not have access to the internet. We didn't have flipped classrooms. I ask my students to look at certain online courses which are in English. Most of the time they don't have a problem with this but when it comes to written exams I need to include the questions in French also to manage students' expectations.

(Lecturer 2: Software engineering)

This uncertainty creates room for agency and flexibility. While the lecturer was careful not to teach in English, she recommends references in English and is able to reflect on the changing needs of her students.

Similar to the arguments made by heads of departments, university lecturers are mindful of the importance of creating language policies that do not disadvantage students and are aligned with local needs and resources. The lecturer referred to in student (1) interview tried to encourage the students to use English in the classroom. Lecturer (1) preferred to involve the students in decisions about the language in which they are taught. Lecturer (2) was not sure that she had the authority to change existing linguistic practices. Overall, there appears to be different approaches to negotiating language policies with students. In some instances, this has created room for flexibility. In others, it has resulted in a sense of uncertainty.

\subsubsection{Students}

Many of the students who took part in this research exhibited features of agency and can arguably be classified as language policy influencers. Students demonstrate evidence of the impact of indirect influencers that (re)shape students' language ideologies and attitudes towards what is needed and valued in their education. This section highlights how students' 
linguistic beliefs were heavily influenced by employers' expectations, scholarships' requirements, and willingness to access international communities of practice. As seen from the previous sections, students' opinions and expectations are highly valued by some lecturers and this assigns some influence to them.

In the following example, a software engineering student talks about how employers' requirements produce favourable language ideologies associated with English:

We are in that transition where all companies are using French and new companies are requiring English skills and we know that employers require interviews in English.

(Student 3: Software engineering)

Given the current socio-economic situation in Tunisia, graduates' employability is on the top of the educational reform agenda (Educational Agenda 2015-2025). This has reinforced the impact of the workplace domain on educational language policies.

Another key domain that affects language policies is access to a wider international community of practice. In the following example from a biology student, he explains that English is required for building international connections:

I need English to say hello world. It is spoken by everyone around the world. I have friends from Japan and Australia. I want to speak with different people...French is not a bad language but the problem is that it is not widely used in the scientific domain. Even French scientists use English. English is more used and is always used.

(Student 4: Biology)

At the same time, this student expresses some contradictions when he describes the different linguistic requirements in the Tunisian job market:

I: Is English required in the job market:

S: A lot of people don't know this or ignore the problem until they face it. English is required. The private sector requires English and the government sector requires French. A lot of people want to work for the government because it offers more job security. 
People can be fired at any second when they work for the private sector. There is no job security.

(Student 4: Biology)

This section brings to the fore a major challenge facing educational language policies in Tunisia. Different employers have different linguistic expectations which makes it harder for students to push for language policies in a particular direction. While the data does not demonstrate evidence that students have agency to change or challenge existing linguistic practices, the data suggests that most decisions about what language to use for instruction factor in students' needs and expectations. At the same time, the employability of university graduates continues to be a pressing issue for the educational reform agenda.

\subsubsection{Perceptions of parents' influence}

While the study did not interview parents, data from two interviews with university lecturers made references to the role of parents as language policy influencers. Parents exercise agency by deciding on whether or not they want to educate their children privately and whether they want their children to develop advanced English skills so they can be more employable. This agency is informed by neoliberal aspirations of social mobility.

In the following quotation, a mathematics lecturer, who is also running her own private English language school, talks about how parents contribute to producing new language ideologies in favour of English in Tunisia:

The mentality in Tunisia is changing. Parents are pushing their kids to study in English from a young age. I have my own English private school and we use Cambridge curriculum. English definitely has future here. .. There is a mind-set change in the country.

(Lecturer 3: Mathematics)

Similarly, an applied linguistics lecturer agrees with this by explaining that: 
People are spending money to send their children to English private classes so that when they grow up, they get ahead of everyone else.

(Lecturer 4: Applied linguistics)

It is worth mentioning that since not all parents can afford to educate their children privately; this agency can create negative consequences that could potentially lead to social inequalities, based on access to advanced English repertoires. This is another negative side of agency as will be discussed in $\mathbf{6 . 2}$.

\subsection{Contesting agency}

Section 6.1 has highlighted the role of different influencers in creating or challenging educational language policies in Tunisian higher education. It also demonstrates the impactful presence of indirect influencers such as employers, scholarships and funding providers, access to recent publications and international communities. In addition, the section provides examples of how the agency exercised by these influencers can create room for flexibility and negotiation and can reinforce the argument that educational language policies need to be decentralised so that institutions can make their own local arrangements based on their needs, demands, aspirations, and resources.

Nonetheless, two university lecturers were very critical of the current 'benign neglect approach' (Piller, 2016) and made arguments against micro-level agency by arguing that it can lead to confusion, inconsistency, and uncertainty. In the following quotation, a university lecturer insists that they should not be the ones who should be approached in order to discuss educational language policies:

Maybe you haven't heard that before but one of the main stakeholders that you should talk to is not lecturers and students. You should talk to politicians. You know it is a political decision. Everything is around politics. I am sorry because you are wasting your time. I can analyse the situation. It is a political decision. They don't want to invest now. 
They are happy with their comfort zone. Everything is in French. They don't want to change because change costs money.

(Lecturer 5: English for Specific Purposes)

Here, the lecturer refuses to claim any agency by explaining that language policies are determined by politicians, not educators. She points out that there has been a lot of investment in the status quo that reinforces the status of French in the educational system and that shifting to English is costly. This view agrees with Boukadi and Troudi (2016, p.12) who point that, 'the amount of money France spends to support and promote French in Tunisia is much higher than the budgets granted by the UK and the US to improve English in Tunisia'.

Although the second university lecturer teaches at the only public institution that teaches through English, she is not sure if what the school is offering matches what is required in the job market. She argues that decisions about the language of instruction should come from the government to avoid confusion and uncertainty:

We're preparing students for what? Are you preparing them for the Tunisian market? Maybe then there is no need for English. But if you are preparing them to leave the country, this is happening now and we don't have to hide this...We should provide positions and an environment that welcomes them. Otherwise, they'll be depressed, anxious and will create problems.

French has reached its limitations. In the past we used to export products and people to a certain market but now we are looking for international people and international products and English facilitates this access. It depends on the orientation of the government. We cannot say for sure that English is the language of the future. The language of the future is the one that goes with the orientation of the government. Where you want to export your products, with whom you want to build relationships, where you see the future of your country. This is not a general rule that will apply to everyone even when we say today that English is key. It is not right all the time

(Lecturer 6: Marketing)

This lecturer refuses to take the status of English in Tunisia for granted and argues that it is 
the government that should decide which languages are important for the economic development of the nation. Her words express feelings of uncertainty. She is not able to confirm that there is synergy between university training and job market demands. She provides an example of this in the following quotation:

Sometimes English is a barrier. If they learn everything in English and are employed in a company where everything required is in French it is difficult for them to shift to French again. At the same time, they will have access to new opportunities. It is hard to tell.

(Lecturer 6: Marketing)

To sum up, this section demonstrates some of the negative consequences of exercising agency in educational language policies at local levels. Even though it is possible for educational stakeholders to defend their decision to challenge the conventional practice of teaching in French, based on wider neoliberal aspirations of social mobility and international membership, this section explains how this agency has also produced sentiments of uncertainty, inconsistency, and instability.

\section{Discussion}

Educational language policies stem from political decisions and ideologies (Tollefson, 1991, 2013). There are always winners and losers, which is why Shohamy (2006) considers language policies as bearers of 'hidden agendas'. Wee (2016, p.332) agrees with this by asserting that 'language policies are inevitably formulated under the influence of particular ideological assumptions'. Language policy researchers in a context such as Tunisia cannot be blind to class interests, historical complexities and political affiliations. Together these factors significantly contribute to the investment in the status quo, which favours French as an unstated official language of governmental institutions including the educational sector.

That is why some of the lecturers in this study reported a sense of uncertainty when 
they were asked whether the educational system would benefit from a shift to English. The hesitation is historically, politically and ideologically constituted; and it stems from a genuine concern about the lives of individuals and communities that are likely to be drastically affected in case of changing the medium of instruction. Wee's $(2016, \mathrm{p} .335)$ notion of 'zombies in language policy' is relevant here: 'what may appear to be zombies from a primary theoretical perspective are in fact still very much alive and kicking when we bring in social intervention'. That is to say, the question of 'what if English becomes the language of instruction?' may have been interpreted by some lecturers as a threat of educational intervention. This brings to the fore the impact of power and ideologies to maintain and reproduce the political status of French in post-independence Tunisia.

On the other hand, the study has demonstrated how some external influencers facilitated institutional agency. Many language policy influencers have called for empowering the status of English. This institutional agency benefits from three enablers. First, this agency is empowered by neoliberal discourses of 'globalisation', 'new economy', ‘internationalisation' and 'modernity'. Such discourses can be described as 'Foucaudian technologies of power' (Rampton, 2016, p. 304). The data presented from lecturers, from students and about parents indicate the dominance of such discourses which seem to provide some legitimacy to the slow and gradual transition to English at tertiary level. The second enabler comes from utilising support from other language policy influencers such as educationalists (heads of departments and lecturers) aiming to internationalise the curriculum, and parents and students thinking about employability prospects, or opportunities to study or work abroad. These influencers provide important support to justify local decisions to change the language of instruction. The third and most important enabler is the absence of official, language policies that determine the languages of instruction at tertiary level, which has created room for agency and decentralised language policies. 
In addition, the study offers valuable insights into some negative sides of agency. While doing so, it responds to Liddicoat's (2019) call for the need to highlight problems and constraints caused by agency in language policy. The study provides evidence that agency in educational language policies can potentially cause inconsistency, uncertainty and can lead to increasing social inequalities in the long term. Agency can cause inconsistency between the different educational institutions which can lead to negative consequences in the job market. For example, graduates who are taught in/through the medium of French might become more or less employable than those educated in/through the medium of English. This also creates a sense of uncertainty which was neatly summarised in lecturer's (6) question when she asks, 'we're preparing students for what?'. Furthermore, agency can lead to a gradual reproduction of social inequalities facilitated by social class. Since access to advanced English is not currently offered through the public educational system, some parents 'top up' the educational input of their children through private education, so that they can be ahead of other children. Some of the university students reported that their peers in private universities receive intensive English language training. These examples illustrate how social class could ultimately regulate access to advanced English repertoires.

I would like to conclude this section with a word of caution from Liyanage and Canagarajah (2019) who problematise the traditional connection between English and social mobility. They argue that there is "no guarantee that English proficiency will improve or change people's life conditions' (2019, p. 3). Similarly, Walter and Benson (2012) raise a question about common perceptions that associate English with access to economic advantages by asking whether this access is real or perceived. Therefore, educational language policies based on neoliberal agendas should not take the neoliberal promises associated with English at face value. In order to provide inclusive and equitable higher education for the Tunisian youth, it is crucial to create effective communication channels 
between the different language policy influencers: 'people with power' (Ministry of Higher Education, Ministry of Education, and major employers), 'people with expertise' (applied linguistics researchers and practitioners), 'people with interest' (parents, strategic developers) and 'people with needs' (university students) ${ }^{1}$.

\section{Conclusion}

Higher education contexts present an opportunity to research educational language policies with an expansive understanding that highlights the impact of different domains such as the family, the marketplace, the publication industry, etc. Doing so, language policy researchers are faced with a larger pool of influencers who use their power in direct or indirect ways. This study has demonstrated the interplay of agency and structure in educational language policies in Tunisia. While the absence of official policies regarding the language of instruction at tertiary level creates room for agency, flexibility, and the ability to make decisions based on local demands and aspirations, the study has highlighted some problems associated with agency such as inconsistency, uncertainty and the potential for agency to (re)produce social inequalities.

\section{Acknowledgments}

I would like to acknowledge the contribution of James Simpson, Martin Lamb, the anonymous reviewers and the Editor in shaping the development of this paper and thank them with gratitude.

1 The first three categories are from Fenton-Smith and Gurney (2016). The fourth category is added by the author. 


\section{Funding}

This research was supported by funding from the British Council: Tunisia.

\section{References}

Baldauf, R. (2006). Rearticulating the case for micro language planning in a language ecology context. Current Issues in Language Planning, 7(2-3), 147-170.

Ball, S. (2006). Education policy and social class. New York, NY: Routledge.

Biesta, G. \& Tedder, M. (2006). How is agency possible? Towards an ecological understanding of agency-as-achievement. Working Paper 5. Exeter: The Learning Lives Project.

Biesta, G., Priestley, M. \& Robinson, S. (2015). The role of beliefs in teacher agency, Teachers and Teaching, 21(6), 624-640.

Bilaniuk, L. (2005). Contested Tongues: Language politics and cultural correction in Ukraine. New York: Cornell University.

Block, D. \& Corona, V. (2019). Critical LPP and the intersection of class, race and language policy and practice in twenty first century Catalonia. Language Policy, 1-21.

Blommaert, J. (1999). Language planning as a discourse on language and society. Language Problems and Language Planning, 20(3), 199-222.

Boukadi S. \& Troudi S. (2017). English education policy in Tunisia. In: R. Kirkpatrick R. (eds) English language education policy in the Middle East and North Africa. Language Policy, 13, 257-277.

Canagarajah, S. (2005). Reclaiming the local in language policy and practice. London: Routledge.

Chouinard, V. (1997). Structure and agency: contested concepts in human geography. The Canadian Geographer/ Le Geographe canadien, 41(4), 363-77.

Creese, A. \& Blackledge, A. (2015). Translanguaging and identity in educational settings. Annual Review of Applied Linguistics, 35, 20-35.

Davis, K. (1994). Language planning in multilingual contexts: Policies, communities, and schools in Luxembourg. Amsterdam: Benjamins.

Daoud, M. (2011). The sociolinguistic situation in Tunisia. International Journal of the Sociology of Language, 211, 9-34. 
Desai, Z. (1995). The evolution of a post-apartheid language policy in South Africa.

European Journal of Intercultural studies, 5(3), 18-25.

Educational reform Agenda in Tunisia 2015-2025 (2015). Retrieved from:

http://www.utm.rnu.tn/utm/documents/projet de la reforme.pdf

Emirbayer, M. \& Mische, A. (1998). What is agency? American Journal of Sociology,103 (4), 962-1023.

Fenton-Smith, B. \& Gurney, L. (2016). Actors and agency in academic language policy and planning. Current Issues in Language Planning, 17(1), 72-87.

Foucault, M. (1980). Power/Knowledge. New York: Harvester Wheatsheaf.

Harvey, L. (2017). Language learning motivation as ideological becoming. System, 65, 69-77.

Hollis, M. (1994). The Philosophy of social science. Cambridge: Cambridge University Press.

Hornberger, N. \& Johnson, D. (2007). Slicing the onion ethnographically. TESOL Quarterly, 41(3), 509-532.

Horner, K. (2009). Language policy mechanisms and social practices in multilingual Luxembourg. Language Problems and Language Planning, 33(2), 101-111.

Johnson, D. \& Johnson, E. (2015). Power and agency in language policy appropriation. Language Policy, 14(3), 221-243.

Johnson, D. (2013). Language policy. Basingstoke, UK: Palgrave Macmillan.

Johnson, D. (2013). Positioning the language policy arbiter. In J. Tollefson (Ed.). Language policies in education (pp.116-136) . New York: Routledge.

Jørgensen, N. (2008). Polylingual languaging around and among children and adolescents. International Journal of Multilingualism, 5(3), 161-176.

Kroskrity, P. (2010). Language ideologies-Evolving perspectives. Society and Language Use, 7(3), 192-205.

Liddicoat, A. \& Taylor-Leech, K. (2014). Micro language planning for multilingual education. Current Issues in Language Planning, 15(3), 237-244.

Liddicoat, A. J. (2019). Constraints on agency in micro-language policy and planning in schools. In J. Bouchard \& G. P. Glasgow (Eds.), Agency in Language Policy and Planning: Critical Inquiries (pp. 149-170). New York: Routledge.

Liyanage, I. \& Canagarajah, S. (2019). Shame in English language teaching. TESOL Quarterly, 53, 430-455. 
Martin, J. (2004). Self-regulated learning, social cognitive theory, and agency, Educational Psychologist, 39(2), 135-145,

Marriott, H. (2006). Micro language planning for student support in a pharmacy faculty. Current Issues in Language Planning, 7(2-3), 328-340.

Otheguy R., García, O., \& Reid, W. (2015). Clarifying translanguaging and deconstructing named languages. Applied Linguistics Review, 6, 281-307.

Pennycook, A. (2002). Language policy and docile bodies. In J. W. Tollefson (Ed.), Language policies in education (pp. 91-110). New York: Routledge.

Pennycook, A. (2006). Postmodernism in language policy. In T. Ricento (Ed.), An Introduction to Language Policy. (pp. 60-76). Malden, MA: Blackwell.

Pennycook, A. (2007). 'The myth of English as an international language' in S. Makoni and A. Pennycook (eds): Disinventing and Reconstituting Languages (pp. 90-115). Clevedon: Multilingual Matters.

Phillipson, R. (2003). English-only Europe? Challenging language policy. London: Routledge.

Piller, I. (2016). Linguistic Diversity and Social Justice. Oxford: Oxford University Press. Rampton, B \& Holmes,S. (2019). How we feel and think about language. Working Papers in Urban Language \& Literacies, (261), 1-7.

Rampton, B. (2016). Foucault, Gumperz and governmentality: Interaction, power and subjectivity in the twenty-first century. In N. Coupland, (Ed.). Sociolinguistics: Theoretical Debates (pp. 303-330). Cambridge: Cambridge University Press.

Ricento, T. \& Hornberger, N. (1996). Unpeeling the onion: Language planning and policy and the ELT professional. TESOL Quarterly, 30(3), 401-427.

Ricento, T. (2000). Historical and theoretical perspectives in language policy and planning. Journal of Sociolinguistics, 4(2), 196-213.

Ricento, T. (2015). Language Policy and Political Economy: English in a Global Context. Oxford: Oxford University Press.

Ricento, T. (2016). Commentary. In E. Barakos and J. Unger (Eds.). Discursive Approaches to Language Policy (pp. 275-286). London: Springer.

Rose, N. (1996). The death of the social? Re-figuring the territory of government. Economy and Society, 25(3), 327-356.

Schiffman, H. (2006). Language policy and linguistic culture. In T. Ricento (Ed.). An Introduction to Language Policy (pp. 111-126). Oxford: Blackwell Publishing. 
Shohamy, E. (2006). Language Policy: Hidden agendas, New approaches. Abingdon: Routledge.

Shohamy, E. (2009). Language policy as experiences. Language Problems and Language Planning, 33(2), 185-189.

Spolsky, B. (2004). Language policy. Cambridge: Cambridge University Press.

Spolsky, B. (2009). Language management. Cambridge: Cambridge University Press.

Spolsky, B. (2012). The Cambridge handbook of language policy. Cambridge: Cambridge University Press.

Sung-Yul Park, J. \& Wee, L. (2012). Markets of English: Linguistic Capital and Language Policy in a Globalizing World. London: Routledge.

Tollefson, J. (1991). Planning Language, Planning Inequality. London and New York: Longman.

Tollefson, J. (2013). Language Policies in Education. Mahwah, NJ: Lawrence Erlbaum Associates.

Walter, S. \& Benson, C. (2012). Language policy and medium of instruction in formal education. In B. Spolsky (Ed.). The Cambridge handbook of language policy (pp. 278-300). Cambridge: Cambridge University Press.

Wee, L. (2016). Are there zombies in language policy? In N. Coupland, (Ed.). Sociolinguistics: theoretical debates (pp. 331-348). Cambridge: Cambridge University Press.

Williams, R. (1977). Marxism and Literature. Oxford: Oxford University Press.

Worldometers. (2019). Tunisian Population. Retrieved from: http://www.worldometers.info/world-population/tunisia-population/

World Bank. (2019). World Bank Country and Lending Groups. Retrieved from: https://datahelpdesk.worldbank.org/knowledgebase/articles/906519-world-bankcountry-and-lending-groups

Zhao, S., \& Baldauf, R. B. (2012). Individual agency in language planning: Chinese script reform as a case study. Language Problems and Language Planning, 36(1), 1-24. 